RESENHA 



\section{A complexidade do fenômeno da terceirização na perspectiva da América Latina}

Alisson Droppa*

BASUALDO, Victoria; MORALES, Diego (Orgs). La tercerización laboral: Orígenes, impacto y claves para su análisis en América Latina. $1^{\mathrm{a}}$ ed. Buenos Aires: SigloVeintiuno Editores, 2014.

Palavras-chave: terceirização; América Latina; contratos de trabalho.

O tema da terceirização tem sido cada vez mais visitado por pesquisadores das mais variadas áreas do conhecimento. No Brasil, por exemplo, os esforços, já há algum tempo, têm se concentrado em explicar o conceito de uma forma que permita exemplificar as diversas formas que o fenômeno apresenta. Segundo Dari Krein ${ }^{1}$ a dificuldade nesse aspecto reside na própria dinâmica dessa forma de contratar, seus contornos variados têm como objetivos principais: a contratação de redes de fornecedores, de empresas especializadas de prestação de serviços de apoio, de trabalho temporário por meio de agências de emprego, de pessoas jurídicas ou de "autônomos" para atividades essenciais, no trabalho a domicílio, nas cooperativas de trabalho e ainda no deslocamento de parte da produção ou de setores desta para ex-empregados.

O livro organizado por Victoria Basualdo e Diego Morales intitulado "La tercerización laboral: Orígenes, impacto y claves para su análisis en América Latina" é resultado de um esforço conjunto entre o Centro de Estudos Legais e Sociais - CELS e a Área de Economia e Tecnologia da Faculdade Latinoamericana de Ciências Sociais - Flacso (Argentina) em ampliar o debate entre os estudiosos da terceirização, principalmente no âmbito da América Latina, trazendo subsídios para a realização de pesquisas comparativas entre as diversas realidades da região com o cuidado de estabelecer os mesmos parâmetros teóricos sobre a temática.

Segundo os organizadores da obra o conceito de terceirização compreende um conjunto de formas jurídicas e de relações de direito. Mas também pode ser ilustrada no momento em que uma empresa estabelece um contrato com "terceiros" e atribui a responsabilidade da realização de uma atividade que

* Doutor em História Social do Trabalho, Pós-doutorando em História pela Universidade Federal de Pelotas com bolsa CAPES/FAPERGS.

1 KREIN, José Dari. As tendências recentes na relação de emprego no Brasil: 1990-2005. (Tese de Doutorado. IE/UNICAMP, Campinas, 2007). 
pode ser de apoio ou periférica, com o intuito de descentralizar a organização das relações originais ou as tarefas centrais anteriormente desempenhadas. Partindo da produção acadêmica em torno da temática, principalmente das últimas décadas, o livro se propõe a dialogar com as publicações recentes, tanto da perspectiva teórica e histórica, como das perspectivas regionais, nacionais ou das atividades empresariais, com o propósito de contribuir no estabelecimento de um arcabouço conceitual comum, visando fortalecer futuras investigações sobre os reais impactos desse fenômeno sobre a classe trabalhadora e sua organização.

A obra está organizada em duas partes. A primeira intitulada "La tercerización en clave global, regional y nacional", subdivida em dois capítulos: iniciando com artigo das pesquisadoras Victoria Basualdo e Maria Alejandra Esponda é intitulado "La expansión de la tercerización a nivel global a mediados de los años setenta, sus antecedentes históricos y su alcance actual”. Seguida da intervenção das mesmas autoras, acompanhadas de Diego Morales, o segundo capítulo intitulado "La tercerización en América Latina en las últimas décadas. Visiones, debates y aportes". Essa primeira parte tem o objetivo de estabelecer parâmetros conceituais para o fenômeno da terceirização em uma perspectiva histórica e regional.

Segundo os autores, responsáveis pela primeira parte do livro, a terceirização não implica necessariamente na descentralização ou desconcentração da produção, ou seja, não pode ser caracterizada unicamente como sinônimo de flexibilização, pois esta pode ser compreendida como uma maneira de eliminar a rigidez do sistema produtivo, incluída a utilização da mão de obra, a qual pode estar relacionada com a diminuição dos custos. Dessa maneira o fenômeno também não pode ser simplesmente confundido com "precarização", onde ocorre o desrespeito a um patamar mínimo de direitos. Esse conceito relaciona-se à terceirização pelo fato de que, em muitos casos, o trabalhador terceirizado trabalha em condições precárias em comparação ao empregado do tomador. Além disso, também deve-se evitar a confusão com os conceitos de informalidade e terceirização, pois o primeiro é uma condição à qual muitos trabalhadores terceirizados são submetidos e o segundo diz respeito à expansão do setor terciário (bens e serviços), a qual nem sempre implica em terceirização.

Os dois capítulos chegam à conclusão de que a terceirização está relacionada com a avaliação da empresa a respeito de que um terceiro poderia realizar determinadas tarefas com maior eficiência e a empresa se concentraria apenas a determinadas atividades. O que leva ao debate do que pode ou não ser terceirizado: tudo, somente as atividades secundárias ou as atividades fim? Outra questão importante abordada diz respeito às formas da terceirização.

Com base fundamentalmente em documento elaborado pelos professores Oscar Uriarte e Natalia Colotuzzo, publicado em 2009, no marco do projeto FSAL/ OIT por meio de convênio com a Central Sindical das Américas, destaca quatro formas de terceirização: em sentido estrito, na intermediação de mão de obra, no fornecimento de mão de obra temporária e na utilização de trabalhadores autônomos.

Em sentido estrito, consiste na operação mediante a qual uma empresa confia à outra o fornecimento de bens e serviços e esta última se compromete a desenvolver as atividades por sua conta e risco, com seus próprios recursos financeiros, materiais e humanos. Na intermediação de mão de obra há a participação de um empregador aparente entre o trabalhador e o verdadeiro 
usuário e beneficiário da prestação dos serviços, formando uma relação triangular. No fornecimento de mão de obra temporária, existem empresas dedicadas a fornecer trabalhadores postos à disposição de outra empresa, a qual definirá e supervisionará as tarefas a serem desenvolvidas. E por fim, na utilização de trabalhadores autônomos, quando os trabalhadores são recrutados de forma independente e trabalham para diversos clientes (autônomos, cooperativas, empresário individual). Segundo essas definições, a terceirização ainda pode ser interna ou externa, dependendo se é realizada dentro ou fora das instalações da empresa; e se externa, se é nacional ou internacional (offshoring, tendência atual de formação de cadeias produtivas globais).

Já na segunda sessão do livro intitulada "La terceirización em la Argentina de la posconvertibilidad: aportes para uma agenda de investigación”, o propósito é apresentar algumas pesquisas com foco na Argentina em relação ao tema da terceirização que, segundo os organizadores do livro, permitem explorar "alguns eixos centrais" do fenômeno e seus impactos sobre os trabalhadores. Está dividida em cinco capítulos: o primeiro sobre o assassinato do sindicalista Mariano Ferreyra, elaborado por Victoria Basualdo, Diego Morales e Andrés López Cabelo, analisa detalhadamente a sentença judicial dos envolvidos no movimento que culminou na morte do ferroviário. Em seguida Laura Perelman analisa a terceirização sob o viés da evolução do mercado de trabalho na Argentina. O quinto capítulo, elaborado por Andrea Del Bono trata dos impactos da terceirização nas negociações coletivas.

O sexto capítulo é escrito por Guillermo Gianibelli e apresenta uma série de aspectos vinculados entre a terceirização e o campo do Direito na Argentina, visando apresentar um conjunto de propostas para modificar a legislação e a fiscalização sobre o tema. O autor relaciona a terceirização como um fenômeno do capitalismo, na busca pelo aumento da acumulação de capital, sendo resumidamente, uma estratégia de desmonte do Direito Social estabelecido por meio do estado ou de negociações coletivas. Ainda aborda especificamente o artigo 30 da Lei $n^{\circ} 20.744$, de 1974, que delimita a responsabilidade como solidária da tomadora frente aos direitos dos trabalhadores terceirizados, salientando que mesmo essa forma de enquadramento não impediu que essa forma de contratação tivesse significativa expansão no mercado de trabalho argentino. Em suma, permite levantar a hipótese de caso o Brasil aprove uma legislação sobre a questão da terceirização, a tendência será um aumento substancial das subcontratações, independente do grau de responsabilização da tomadora.

Por fim, o último capítulo, analisa a terceirização por meio de testemunhos de trabalhadores de diversos setores: têxteis, metalúrgicos, telefônicos, call centers e bancários estatais buscando abordar um conjunto de visões e experiências sobre a terceirização do ponto de vista dos trabalhadores. Esse último capítulo permite compreender a existência de diferentes aspectos de condições de trabalho e disciplinamento como uma estratégia patronal e seus impactos na fragmentação e divisão dos sindicados.

De acordo como mencionado anteriormente, o livro buscou demonstrar que a terceirização é um fenômeno complexo, com uma multiplicidade de "vestimentas" e uma diversidade de manifestações que dificultam em muito o estabelecimento de parâmetros universais com o intuito de quantificar e comparar seus impactos nas diferentes realidades latinoamericanas. Mesmo assim, o principal mérito da obra é propor o estabelecimento de critérios conceituais mínimos que poderão ser utilizados para a criação de uma agenda sistemática de investigação que poderá 
permitir o aprofundamento da compreensão do funcionamento e da prática da terceirização na América Latina ao longo dos anos. Além de seus principais impactos no mundo do trabalho.

Recebido em 11/12/2015

Aprovado em 17/12/2015 